\title{
“NÃo É ESSE O Ofício dos DEUSES?” A SÁtiRA E O TAMANHO REAL dos GRANDES hOMENS do EXÍlio em MarX E Machado de Assis
}

Ana Laura dos Reis CORREA*

ELISABETH HESS ${ }^{* *}$

\section{RESUMO}

Este artigo aborda a composição satírica de dois textos diferentes quanto ao gênero, ao espaço e ao tempo: Os grandes homens do exílio, texto político e paródico, escrito em Londres, no ano de 1852, por Marx, Engels, Ernst Dronke e Jenny von Westphalen, e "Conto alexandrino", narrativa ficcional de Machado de Assis, publicada em 1883, no Rio de Janeiro. Sem desconsiderar essas diferenças entre os textos, a análise busca compreender a que necessidade responde essa escolha dos autores pela sátira, concretizada a partir da configuração de personagens que, no exílio, assumem uma estatura que não corresponde ao seu tamanho real.

Palavras-chave: sátira, Os grandes homens do exílio, Marx, "Conto alexandrino", Machado de Assis.

Marx e os coautores de Os grandes homens do exílio utilizam a sátira para expor a estatura pequeno-burguesa de alemães exilados em Londres no período pós-revolucionário, os quais, alçados aos olhos do público à altura de "grandes homens", heróis da Alemanha, gênios poéticos, deuses esclarecidos, líderes revolucionários, lançavam sua sombra sobre os revolucionários anônimos mortos nas batalhas de 1848 e, tecendo o casulo de sua subjetividade poética caricatural e de sua filosofia idealista decadente, engrossavam as tramas do filisteísmo reacionário alemão.

* Doutorado em Literatura pela Universidade de Brasília (UNB), Brasília, Brasil. E-mail: analauradosreiscorrea@gmail.com

** Mestrado em Literatura pela Universidade de Brasília, Brasil (UNB), Brasília, Brasil. E-mail: eishess@yahoo.com.br 
No Brasil, em "Conto alexandrino", Machado de Assis (2007) também escreve sobre grandes homens exilados: os filósofos metafísicos Pítias e Stroibus. Este último, também grande anatomista, defendia a doutrina de que os deuses puseram nos bichos "a essência de todos os sentimentos e capacidades humanas" e bastaria uma espécie primitiva de transfusão sanguínea para que o sangue de um rato transformasse um homem honesto em ladrão e o de uma rola para que um infiel se tornasse o maior exemplo da fidelidade conjugal. Como "ninguém é profeta em sua terra", deixam juntos a sua Chipre para conquistar, com sua doutrina, a Alexandria, "onde as artes e as ciências eram grandemente honradas" (ASSIS, 2007, p. 192). Com uma estrutura satírica rascante, Machado responde à pergunta feita por um alexandrino anônimo aos dois filósofos que prometiam "reconstruir os homens e os Estados": "Não é esse o ofício dos deuses?" (ASSIS, 2007, p. 193). A resposta satírica desvela, sob a metafísica, a perspectiva histórica decadente, cuja dimensão perversa encontrará mais tarde, sob o fascismo, sua realização acabada.

Oobjetivo deste artigo não é fazer uma aproximação imediata entre o texto de Marx, Engels, Dronke e Jenny von Westphalen - Os grandes homens do exílio - e o de Machado de Assis - "Conto alexandrino"-, pois os textos possuem especificidades que os diferenciam tanto na sua motivação originária - o primeiro tem uma função política, ancorada numa paródia literária, enquanto o segundo é eminentemente ficcional -, quanto também no que diz respeito ao tempo e ao espaço de sua produção: o texto de Marx foi escrito em 1852, em Londres, enquanto o de Machado, em 1883, no Rio de Janeiro. Pretendemos ressaltar a natureza satírica do modo de composição de ambos e buscar entender a que necessidade responde essa escolha dos autores pela sátira, que se apresenta talvez como o lugar onde textos tão diferentes se encontram.

$\mathrm{O}$ texto de $O s$ grandes homens do exílio foi escrito quando o próprio Marx vivia a experiência do exílio na Inglaterra e produzido de forma coletiva: Marx, Engels e Ernest Dronke figuram como autores na edição das Obras Completas de Marx e Engels (MEGA) de 1985, mas outros membros da Liga dos Comunistas, com destaque para a participação de Jenny von Westphalen, participaram da coleta de material para a composição do texto, que, no entanto, não foi impresso à época. $\mathrm{O}$ destino desse texto tem ele mesmo um caráter anedótico que 
remonta à atmosfera que ele capta e para a qual foi escrito: o manuscrito foi vendido por Marx, por 27 libras, a um húngaro, conhecido por Banya, que se ofereceu para intermediar a sua publicação, mas Banya era, na verdade, um espião da polícia prussiana, nas mãos de quem o texto desapareceu sem ter préstimo algum para as investigações, uma vez que se tratava de uma paródia burlesca dos intentos revolucionários completamente fantasiosos dos exilados alemães na Inglaterra derrotados em 1848 que se apresentavam ao público como grandes heróis da revolução; ou seja, a sátira no texto se efetivou como sátira na vida, reveladora da própria dinâmica rocambolesca da espionagem policialesca, que recebeu sobre si o golpe satírico do texto, cujo alvo era inicialmente outro. O original que estava com Engels, que afortunadamente não precisou vendê-lo, passou pelas mãos do editor Bernstein que, além de não demonstrar interesse algum pelo texto, apagou as poucas referências a ele na correspondência de Marx e Engels. Assim, o texto só veio a público pela primeira vez em 1930, numa edição russa do Instituto Marx-Engels de Moscou, e, portanto, à sombra da política cultural burocratizada estalinista, também não pôde chegar livre e amplamente aos leitores de Marx.

Laura Sotelo, que traduziu o texto para o espanhol em 2015, atribui esse desinteresse por Os grandes homens do exílio ao efeito perturbador que uma obra assim irreverente e violentamente satírica causaria "ao conformismo intelectual social democrata, e o quanto seria nociva ao autoritarismo soviético", ao apresentar "líderes democratas radicais, como Kinkel e ainda os mais vermelhos, como Willich, [...] como egocêntricos culturalmente conservadores, convencidos de seu papel histórico supremo" - justamente "no momento em que posavam, frente à opinião pública,como profetas chamados a dividir o Mar Vermelho" (SOTELO, 2015, p. 11, tradução nossa).

Sotelo, entretanto, vê, nessa fúria satírica do texto, alguns elementos interessantes, entre os quais destacamos dois: 1) O quanto essa forma conduzida pela sátira, "mescla de história, literatura, humor e detração descarada", rechaça a estrutura mecanicista e dogmática do esquematismo a que a obra de Marx foi e é, muitas vezes, submetida, dissolvendo "o duro registro do materialismo vulgar em águas revoltas e burlescas" (SOTELO, 2015, p. 10-11, tradução nossa); e 2) Como o caráter "total" do modo de composição satírico adotado por Marx 
- "a conjunção laboriosa entre ciência, filosofia, literatura e política" (SOTELO, 2015, p. 44, tradução nossa) -, presente não apenas neste texto, mas no conjunto de sua obra, resulta numa forma dinâmica e viva, que nem se limita a uma dedução direta das bases econômicas, na perspectiva de movimento unívoco da infraestrutura para a superestrutura, como produto meramente passivo da vida social, nem tampouco se resume a mero recurso estilístico,construções discursivas puras, sem vínculos com as classes e interesses históricos.

Sotelo (2015) vê na dimensão satírica e farsesca adotada por Marx a escolha de uma chave, pelas armas da literatura, tanto para a crítica do presente, quanto para a "poesia do devir". A sátira em Marx funciona como um convite ao abandono de roteiros instituídos e à desalienação das novas gerações que invocavam o passado como legitimador. $\mathrm{Na}$ paródia satírica de Marx, os personagens vêm de épocas e obras do passado, mas interpretam uma segunda versão modificada, que revela a defasagem histórica entre o conteúdo da nova revolução proletária e suas formas tradicionais de expressão, ainda burguesas. Esse modo satírico se apresenta com clareza na famosa passagem d' $O 18$ de Brumário de Luís Bonaparte:

Em alguma passagem de suas obras, Hegel comenta que todos os grandes fatos e todos os grandes personagens da história mundial são encenados, por assim dizer, duas vezes. Ele se esqueceu de acrescentar: a primeira vez como tragédia a segunda como farsa. Caussidière como Danton, Louis Blanc como Robespierre, a Montanha de 1848-1851 como a Montanha de 1793-1795, o sobrinho [Luís Bonaparte] como o tio [Napoleão Bonaparte]. E essa mesma caricatura se repete nas circunstâncias que envolvem a reedição do 18 Brumário! (MARX, 2011, p. 25, grifo nosso)

Essa dinâmica satírica potente atravessa toda a obra de Marx, desde a juventude ${ }^{1}$ até à maturidade, caracterizando-se, portanto, como um modo estruturante de captar a realidade, que recusa o falseamento do objeto ao desnudar, como caricatura, o que já existe na própria vida como caricatura, operando um movimento de rebaixamento da aparência grandiosa ao tamanho correto de sua essência histórica real. A sátira é, assim, um modo de compor realista, que não se resume ao limite de uma crítica individual, mas que é capaz de fazer aparecer nos 
contornos da singularidade as forças históricas que atuam na realidade como tendência à regressão da humanidade, à fetichização da vida, o que faz da sátira uma forma de combate aberto em favor da emancipação humana.

Em Os grandes homens do exilio, observamos exatamente esse movimento compositivo de desfetichização satírica. Um dos capítulos do texto se dedica à paródia da autobiografia de Gottfried Kinkel, publicada em 1850 sob o título pomposo e melancólico de Verdade sem poesia. Na paródia da Liga Comunista, a pretensão objetivista e universal de Kinkel em relação à história é desmascarada a partir de suas próprias palavras e posicionamentos frente à realidade, que, na sátira, assumem sua real dimensão limitada à deformação subjetivista e estreita da realidade. Como observa Francisco García Chicote (2018), a sátira de Marx e seus companheiros ao livro de Kinkel reduz a aparência grandiosa da autobiografia a seu tamanho verdadeiro, o de uma fanfarronada:

A fanfarronada do personagem apresenta duas manifestações salientes: por um lado, o desenvolvimento de um conceito de formação e de experiência que não têm fundamento nas práxis, mas, antes, precisamente na retração do indivíduo à sua interioridade e na predileção ou por um passado falseado ou por um futuro que não é apenas fantasioso, mas que também implica uma irresponsabilidade para com as tarefas do presente. [...] Esta relutância à ação se encontra associada, por outro lado, a uma aparência de ação, uma vez que o conceito moderno de caráter exige ser colocado à prova em sua relação com o meio.Aqui sobressai o que Marx e Engels denominam "mentira romântica", cuja "íntima essência" é o disfarce: não se busca a resolução de problema algum, não se procura nenhuma aproximação autêntica ao objeto, pois simplesmente o que importa é unicamente que o outro reconheça a aparência como essência. (CHICOTE, 2018, p. 74, tradução nossa, grifos do autor)

A autobiografia de Kinkel, como expressão da convenção romântico-burguesa que é, embora se pretenda mostrar como apreensão objetiva da luta revolucionária, quando submetida à sátira, exala todo o mofo das tendências mais reacionárias da cultura e da ideologia romântica, que, desconectadas das raízes vitais, reproduz o fetiche das

Corrêa, A. L. dos. R; Hess, E. "Não é esse o ofício dos deuses?” A sátira e o tamanho 
flores mortas. Como afirma Sotelo (2015), a sátira da autobiografia de Kinkel dá a ela a forma lacrimosa da novela sentimental burguesa, a sua forma verdadeira:

Kinkel se transforma, na apresentação satírica, em uma figura alegórica de tendências tradicionalistas da cultura, personagem eclético formado pelo emparelhamento de vários autores: sua imaginação utópica é nutrida pelos devaneios da "Flor azul" de Novalis, sua fantasia erótica das cenas de Wilhelm Meister de Goethe, sua sensibilidade política, da resignação lúgubre de Miller. O próprio de Kinkel é não ter nada de próprio. Todas as suas experiências foram moldadas por cenas de uma literatura consagrada; mais que uma vida autêntica, Kinkel é uma vida assegurada em uma herança sem inventividade. (SOTELO, 2015, p. 33, tradução e grifos nossos)

A vacuidade da figura de Kinkel se torna visível pela estratégia da composição satírica adotada pelos autores, que demonstra o quanto o falseamento subjetivista romântico da realidade é uma deformação não só da objetividade, mas também da própria subjetividade de homens tão excelentes, mas, na verdade, inexistentes! A sátira, assim, é um modo compositivo extremamente adequado para alcançar a realidade sem disfarces no interior de um mundo em que predomina o disfarce, daí sua potência realista desfetichizadora, capaz de desfazer também o crédito dado pelo romantismo ao isolamento do sujeito em relação à sociedade; a poetização da completa cisão entre mundo interior e vida exterior se apresenta, pela sátira, como desajuste fetichista a ser superado pela necessidade da ação humana emancipadora frente ao presente.

No capítulo "A Grande Guerra entre os sapos e os ratos", de $O s$ grandes homens do exílio, os autores, utilizando elementos extraídos do Orlando Inamorato, de Boiardo, e personagens de Cervantes - D. Quixote e Sancho Pança -, entre muitas outras referências literárias, inserem a disputa entre exilados alemães do Norte (Gottfried Kinkel) e do Sul (Arnold Ruge) no quadro da Batracomiomaquia, atribuída a Homero. Nela, o vocabulário épico é utilizado para tratar de um tema cômico - a terrível guerra entre sapos e ratos, causada por um motivo torpe e covarde, um sapo que, levando um rato até a outra margem do rio, o deixa afogar e ouve a seguinte maldição que prediz o conflito: 
Teu proceder não haverá de passar despercebido, ó Inchabochechas, que este náufrago fizeste despencar do teu corpo como uma pedra. Em terra, ó mui perversa, não me vencerias nem no vale-tudo, nem na luta, nem na corrida; mas te valeste da fraude para jogar-me n'água. Tem a divindade um olho vingador e pagarás teu crime ao exército de ratos, sem que consigas escapar. E assim expirou ele na água. (COSTA, 2009, p. 57.)

Em Os grandes homens do exilio, a disputa das duas facções de exilados é, como no poema heroico-cômico, narrada com uma grandiloquência sarcástica insistente: "Assim se produziu a ruptura violenta entre o Clube da emigração e o Clube da agitação, que se abre como um abismo, dividindo toda a história universal moderna" (MARX et al., 2015, p. 221). A distorção no sentido do exagero da ação épica produz como efeito satírico o desmascaramento da aparente grandiloquência que esses exilados pretendiam figurar como essência, deixando evidente o tamanho real desses homens e a mesquinhez de seus altos ideais românticos:

Ambas as partes, ou seja, todos os "homens notáveis" tinham em comum o fato de que dominavam a massa de emigrados pelo cabresto, escondiam deles seus objetivos reais, usavam-nos como meras ferramentas e os largavam assim que eles serviam ao seu propósito. (MARX et al., 2015, p. 212, tradução nossa)

Mais uma vez, o texto apresenta, de forma caricatural, homens que na vida real são efetivamente apenas caricaturas de revolucionários. Assim, se desvelam não só os traços pequeno-burgueses desses heróis do exílio, mas também a ineficácia da luta que se vangloriam de liderar: a sobrelevação satírica na narrativa da ação épica deixa em relevo justamente o seu oposto, a absoluta ausência de ação efetiva por parte desses "homens notáveis", que, como afirma Engels, ao contrário da ação revolucionária das vítimas anônimas de 48,

se reuniam em Londres aos magotes para formar governos provisórios futuros, não só para suas respectivas pátrias, mas para toda a Europa, e para isso só faltava receber o dinheiro necessário dos Estados Unidos, um empréstimo revolucionário, para que realizas- 
sem, num abrir e fechar de olhos, a revolução europeia. (ENGELS, 1982, p. 200)

Marx, Engels e o grupo de autores reunidos na composição de $O s$ grandes homens do exilio, evidentemente, se opuseram firmemente a essa posição, e a sátira era a única forma possível de encarar a proposta de uma ação romântica respaldada em um "empréstimo revolucionário"; só a ridicularização satírica poderia dar conta de mostrar adequadamente a defasagem entre a nociva fantasia revolucionária decadente e as necessidades reais de transformação, pois

as diversas querelas em que agora as duas fracções isoladas do partido Continental da ordem se perdem e mutuamente se comprometem, muito longe de darem ocasião a novas revoluções, são, pelo contrário, possíveis apenas por que a base das relações é momentaneamente tão segura e - o que a reação não sabe - tão burguesa. Nela, todas as tentativas da reação que travam o desenvolvimento burguês farão tão seguramente ricochete como toda a indignação moral e todas as proclamações entusiásticas dos democratas. (ENGELS, 1982, p. 211, grifo do autor $)^{2}$

Essa passagem d'Os grandes homens do exílio, cotejada com as explicações de Engels (1982) em "Para a história da Ligas Comunistas", deixa ver que a sátira, como um método criador, também individualiza para alcançar uma tendência concreta mais geral da vida mesma; a sátira é completamente livre de

toda moralidade, a sátira dirige seu ímpeto destruidor ao objeto desde o objeto e se torna, assim, uma autêntica ferramenta de crítica materialista, $[\ldots]$ seu produto é refratário à manipulação, seu estatuto geral é precisamente uma recusa de toda violência subjetiva deformante. (CHICOTE, 2015, p. 532, tradução nossa)

Como na Batracomiomaquia da Antiguidade, em Os grandes homens do exílio, a partir de uma linguagem grandiloquente inadequada à pequenez do feito narrado, o movimento satírico é de rebaixamento do objeto satirizado e vai na direção oposta à elevação e ao engrandecimento assumido pelos revolucionários pequeno-burgueses diante de si mesmos e da realidade histórica.Esse rebaixamento, no entanto, não 
corresponde a uma crítica moral regida pelas convenções estabelecidas, muito ao contrário, a sátira é o desmascaramento do caráter esvaziado da moral burguesa. O jovem Marx, já um crítico do idealismo alemão e avesso aos parvenus acadêmicos, via na sátira uma forma crítica desvencilhada do moralismo policialesco. Em 1837, com apenas dezenove anos, Marx escreve, em razão do sexagésimo aniversário de seu pai, um breve romance satírico - Escorpião e Félix -, ironizando a moral e as convenções burguesas. Nesse texto se evidenciam alguns elementos advindos do romance satírico de Lawrence Sterne - Tristram Shandy -, que reaparecem em 1852 n'Os grandes homens do exilio: a presença de digressões entrecortando a linha condutora do pensamento, o grande número de referências literárias, as menções a filósofos dos séculos imediatamente precedentes. Em 1842, em artigo da Gazeta Renana a respeito da censura alemã aos seus textos jornalísticos, é possível perceber o quanto essa concepção satírica, aproximada à de Sterne, é algo já profundamente enraizado na forma que perpassaria o conjunto de toda a obra de Marx:

Sou humorista, mas a lei me obriga a escrever de modo sério. Sou atrevido, mais a lei ordena que meu estilo seja discreto. Ademais, se a seriedade não se ajusta àquela definição de Tristram Shandy - segundo a qual ela é um comportamento farisaico do corpo, destinado a encobrir as deficiências da alma - e passa a significar a seriedade material, suspende-se então a prescrição inteira. Pois trato seriamente o risível quando o trato risivelmente, e a mais séria imodéstia do espírito é ser modesto diante da imodéstia. (MARX, 2018, p. 11)

Nessa passagem, Marx sublinha um elemento central da sátira "trato seriamente o risível quando o trato risivelmente" - a justificativa para o tratamento jocoso da matéria social não é estritamente subjetiva, mas decorre da forma de ser objetiva da matéria a ser tratada, isto é, trata-se do fato de que o conteúdo social é, em sua própria materialidade, da ordem do risível e, não, fruto de uma deformação subjetiva, moral e submissa às convenções burguesas. Isso possibilita a configuração desfetichizada da realidade imediata, uma vez que desfaz a ilusão sancionada por aqueles que zelam pelo respeito às tradições e vigiam o cumprimento e a repetição dos bons costumes, os heroicos homens de bem. Assim, enraizada na essência da vida concreta, a sátira possibilita 
a inteligibilidade da inversão estampada na aparência ao escancarar a imodéstia dos modestos e revelar a modéstia dos considerados imodestos: o tamanho real dos grandes homens do exílio. A sátira à pequenez dos grandes revolucionários afirma a grandeza dos revolucionários anônimos mortos nas batalhas de 1848. Mas, pelo tratamento risível, a visibilidade dessa inversão farsesca vigente na imediatez da vida burguesa não se configura de modo trágico, fatal e imutável, mas como forma crítica apreensível, não desesperada, na sua dimensão exata de contingência que enseja a mudança e o historicamente novo:

a última fase de uma figura da história universal é sua comédia. Os deuses da Grécia, já mortalmente feridos uma vez de modo trágico, no Prometeu acorrentado de Ésquilo, deviam morrer outra vez, agora de modo cômico nos diálogos de Luciano. Por que a história tem tal andamento? Para que a humanidade possa se libertar serenamente de seu passado. (MARX, 2017, p. 25)

Libertar-se do passado, no sentido de superá-lo, de não o repetir no presente em dimensão farsesca é um resultado da arma da sátira, que faz morrer, serenamente, o passado e abre caminho para o novo no interior do desenvolvimento histórico da humanidade. Mas tal libertação serena do passado que aponta para um devir ainda seria possível no momento histórico do capitalismo decadente ou estaria restrita à infância da humanidade, a Antiguidade Clássica? Essa questão, que demonstra o nó impossível de ser desatado entre forma estética e matéria social, nos leva ao fato de que a sátira, como forma realista de captar a vida em sua dinâmica ativa e mutável, não pode ser estreitamente individualizada, ancorada numa percepção moralista do sujeito satirizado, nem pode ser inteiramente abstrata, apenas uma estilística, descarnada de singularidades históricas. Nesse sentido, a sátira alcança a relação entre o sujeito e o mundo, mas, não nos limites da perspectiva romântica que decreta a cisão irreconciliável entre o sujeito, cujo alma se refugia satisfeita num mundo interno poético e elevado, e o mundo externo, despoetizado e decadente. Ao contrário, na sátira, o contraste entre o sujeito e o mundo é conformado pela justaposição imediata entre aparência e essência, determinada pala própria materialidade dinâmica da vida. 
Considerando-se essa conformação satírica, é possível perceber a potência realista e desfetichizante da sátira frente à hostilidade do capitalismo ao desenvolvimento das potencialidades humanas. Sem a moralidade e a tragicidade da ideologia romântica, e poderíamos dizer ainda, em relação a um momento histórico posterior a Marx, sem o fatalismo naturalista, o conflito entre o sujeito e o mundo pode ser configurado pela sátira como unidade contraditória que exige superação, mas sem se render ao idealismo deformante nem à resignação determinista. A sátira seria então uma forma serena, isto é, inteligível (e, não, irracional ou positivista) de libertar-se de uma condição anterior e abrir-se para uma perspectiva de devir emancipatório.

Laura Sotelo, entretanto, entende essa libertação satírica em sentido diverso: como forma de reencontro não moralizante, mas familiar, entre o sujeito e o mundo. Retomando a concepção aristotélica acerca da comédia, na qual, ao contrário do que ocorre na tragédia e na epopeia, não são representados homens superiores a nós, mas exatamente aqueles ditos inferiores, que estão em oposição aos heróis sobrehumanos e aos deuses, Sotelo (2015) lembra que o riso satírico é, na definição antiga, "como um erro sem dor", pelo qual alguma superação parece ser possível. Sotelo (2015) afirma sobre Os grandes homens do exílio, evocando Bakhtin e Adorno, que há no riso satírico, sob o rebaixamento e a inferiorização do objeto, um elemento liberador, que destrói o medo, estabelece um contato familiar entre o sujeito e o mundo e que "permite liberar o conteúdo repressivo de suas idealizações como 'grandes homens', frente ao quais se apequenam as vítimas anônimas das revoluções de 48"; o que significaria uma liberação, pelo riso, dos próprios adversários detratados, livres agora "do peso excessivo, quase divino, que imaginavam ter sobre a história" (SOTELO, 2015, p. 11, tradução nossa). Estariam todos, então, na escala humana real.

No entanto, se a sátira aponta para o futuro, para uma poesia do devir, em que todos estariam na escala humana real, como afirma Sotelo (2015), por outro lado, a forma do texto de Marx, como observa Chicote (2015), lança mão de um elemento compositivo que também deixa aceso o conflito, o embate aberto entre a posição dos grandes que são historicamente pequenos e a dos pequenos que são factualmente grandes, no que diz respeito às ações humanas no andamento do desenvolvimento histórico. Trata-se do emprego da saturação, que 
tanto reflete a percepção exagerada da autobiografia dos ilustres quanto a duplica por meio da moldura dourada rocambolesca e irônica com que Marx a enquadra reiteradamente. Como lembra Chicote (2015), o termo satura mantém relações etimológicas com sátira: trata-se da Satura Lanx, a bandeja das primícias, uma honra à deusa Ceres, divindade da sementeira, que recebia um prato com os primeiros frutos colhidos, ofertado por aqueles que foram satisfeitos ou saturados por uma boa colheita. Segundo Chicote (2015), esse recurso formal satírico confere, de forma não casual, ao próprio texto de Marx uma configuração saturada, e "de fato, o prato logrado por Marx e Engels é difícil de tragar" (CHICOTE, 2015, p. 534, tradução nossa). Essa dificuldade formal, acreditamos, é um entrave estético-histórico satirizante, que, ao fazer o leitor engasgar, impede a satisfação efetiva e afasta a possibilidade de uma reconciliação idealista, no interior do texto, entre o sujeito e o mundo, que apague a necessidade de uma efetiva transformação de ambos na realidade material e histórica.

Como analisa Lukács (2011), essa impossibilidade de reconciliação idealista fez Hegel considerar a sátira um gênero imperfeito, uma vez que a reconciliação, condição que Hegel reputa como indispensável para uma figuração realmente artística, embora seja possível no humor, se demonstra impossível na sátira. Para Schiller, Hegel e Vischer, estetas analisados por Lukács (2011) em seu ensaio "A questão da sátira", o efeito satírico resulta do contraste imediato entre essência e aparência, contraste que no alto grau de alienação desse momento do desenvolvimento do capitalismo se mostra mais hostil e muito distante do mundo antigo, como observa Salinas (2015) ao comentar a relação entre Os grandes homens do exílio e Os deuses no exílio, de Heine, onde os deuses,

despojados de seu poder, se ocultam 'entre nós', no marco de uma vida cotidiana trivial e regulada, na qual só através de ofícios burgueses podem aceder, não mais ao néctar que lhes era ofertado no Olimpo, mas, sim, à cerveja que se oferta nas tabernas [...]" (SALINAS, 2015, on-line, tradução nossa)

Por outro lado, essa saturação indigesta da sátira confere à arte uma atitude de mobilização desalienante, na medida em que, na sátira, 
“a simples possibilidade do objeto da representação satírica é suficiente para desmascarar o sistema figurado e revelar sua essência real, [...] quando a simples possibilidade de um evento contingente surge como a essência oculta do objeto" (LUKÁCS, 2011, p. 174).

Reconhecemos a presença desse elemento de saturação, que impede a reconciliação idealista, mas impele à desalienação, também no "Conto alexandrino", de Machado de Assis, que era, assim como Marx, um leitor atento da sátira de Lawrence Sterne. O "Conto alexandrino" é ambientado no mundo antigo, na grande Alexandria de Ptolomeu, que acolhe dois filósofos de Chipre: Stroibus e Pítias. Incompreendidos na sua terra natal, buscam exílio numa cidade que consideram avançada o suficiente para receber os benefícios de sua doutrina, capaz de reconstruir a humanidade e distribuir talentos e virtudes. Essa novidade filosófica foi largamente anunciada ao público, sem que fosse, no entanto, explicitado o seu método, que consistia numa espécie de transfusão do sangue de um determinado animal, que guardava em si o princípio dos sentimentos humanos, para o corpo de um ser humano, que, assim, se transmutaria de honesto a ladrão, caso recebesse o sangue de um rato, ou de inculto a geômetra e músico, caso o sangue fosse de uma aranha! Ante a propaganda dos exilados, um garoto alexandrino pergunta se o que intentavam os filósofos não seria ofício exclusivo dos deuses. A resposta de Stroibus é uma definição de si mesmo como uma deidade esclarecida: "Eu violei o segredo dos deuses [...] eu descobri as leis da gramática divina" (ASSIS, 2007, p.193). Quando o alexandrino lhe pede - "Explica-te" -, ele alega que precisa fazer experimentos e promete, longe de toda racionalidade, que dará aos homens uma riqueza que jamais poderiam receber de outro homem, reforçando mais uma vez a sua generosa superioridade, que não deixa de lembrar Brás Cubas, o emplasto e os cálculos regidos pelo amor da glória.

Nesse ponto, temos à vista uma problemática própria do romantismo europeu que, crítico às relações mediadas pelo caráter abstrato do trabalho, enxerga a lógica árida que o desenvolvimento científico assume no capitalismo e coloca na conta de grande ingenuidade a marcha iluminista que pretendia desmistificar a vida. E, apesar dessa crítica se revelar pertinente no decorrer dos acontecimentos do conto, a doutrina apresentada por Stroibus já se revela disparatada desde o início, 
através da demonstração de descrença do amigo Pítias. Fica claro que não há base empírica suficiente para aquela teoria parecer verdadeira e, não obstante, sem explicitar os motivos subjetivos, Pítias se prontifica a estudar a hipótese e se tornar discípulo de Stroibus. Assim, no conto, essa temática não é elevada ao nível do drama que centraliza um caráter como o de Dr. Frankenstein, por exemplo, mas é permeada pela atmosfera farsesca que organiza seu quadro de decadência.

A saturação no conto, diferentemente do texto de Marx e seus companheiros da Liga Comunista, não deriva da configuração formal exagerada do conto, que desse ponto de vista é palatável, atraente e bem temperado, com pitadas de humor. Ela advém, como ideia fixa, da crescente obsessão dos filósofos com os experimentos, que, cada vez mais distantes de qualquer racionalidade, vão adquirindo um feitio científico-mágico-mercantil, uma vez que eles se tornam suas próprias cobaias e, recebendo sangue dos ratos, o que começa a tornar a narrativa indigesta, transformam-se em ladrões contumazes, ao mesmo tempo em que alcançam um alto reconhecimento que lhes garante livre ingresso à famosa Biblioteca de Alexandria, de onde subtraem diversos volumes que pretendiam negociar mundo afora, entre eles um Homero e a República de Platão. No momento da fuga, no entanto, foram pegos em flagrante e entregues, por Ptolomeu, a Herófilo, inventor da anatomia.

É a partir desse momento, no capítulo final do conto, que a saturação vem à tona, uma vez que, em nome da ciência, em nome da verdade imortal, Herófilo pede a Ptolomeu não os ratos, cães, gansos ou lebres de Stroibus para estripá-los, mas, homens vivos, que, segundo ele, já nem se podem mais dizer homens: os criminosos, que "ocupam na escala humana um grau muito inferior"(ASSIS, 2007, p. 197) e podem até ser redimidos ao prestarem serviço à ciência e à verdade, que é imortal e vale não só todos os ratos, como todos os delinquentes do universo. Depois que Ptolomeu considerou tal raciocínio exato e que na cidade não houve nenhuma manifestação contra a medida, salvo alguns pedidos verbais, os presos começaram a ser estripados, sem que suspeitassem de seu "destino científico", descoberto apenas "quando os anatomistas definiam o objeto do estudo do dia, alçavam os ferros e davam os primeiros talhos" (ASSIS, 2007, p. 198). Assim, como os supliciados que padeciam em dobro por terem conhecimento da experiência anterior feita com os ratos, também o leitor tem dificuldades 
para prosseguir a leitura, que evoca tanto o suplício histórico de corpos negros na escravidão, consumado no passado do texto de 1883, quanto os experimentos com seres humanos do nazi-fascismo que se realizariam no que ainda é futuro para o texto de Machado.

E ainda que o espaço no conto nos ofereça uma trama bem situada e distante, esse é o momento em que o mordente da sátira ganha uma perspectiva que aprofunda a dimensão histórica. Antes disso, os dois filósofos se passavam por tolos, diante dos leitores, quando resolviam experimentar neles mesmos o princípio do sangue do rato e quando justificam o sacrifício de si ou a firmeza da vivissecção dos ratos com o digno propósito da ciência. Suas características de grandes sábios são prontamente rebaixadas alternadamente após serem objeto de celebração e reconhecimento dos habitantes da grande cidade, assim como suas doutrinas atuais parecem contrariar princípios de seus antigos tratados. O caráter de farsa está identificado até então com as personagens Stroibus e Pítias e o tom cômico persiste enquanto esses grandes filósofos enganam a si e aos demais com aquele despropósito metafísico que encontraria respaldo apenas naquela experiência decisiva. Seguindo as leis clássicas da comédia, o desfecho não haveria de causar dor ou ruína. Mas ao chegar na citada reflexão de Herófilo de que a verdade é imortal e "vale não só todos os ratos, como todos os delinquentes do universo" (ASSIS, 2007, p. 197), percebemos que a mudança da sorte se apresenta com um travo que foge ao desfecho cômico próprio de uma sociedade superior que é capaz de devolver cada coisa ao seu devido lugar de forma a sair ela incólume de toda a fábula. A premissa da ciência imortal é trazida novamente não para promover um desfecho trágico que elevaria a qualidade de Stroibus e Pítias, mas para estender o rebaixamento àqueles grandes homens que desejam a aparência de serem representantes de tão superior verdade. A premissa fica mais ameaçadora para os dois ilustres ratoneiros enquanto vemos o jogo de cena se perpetuar a serviço da verdade imortal que loureia o notável Herófilo.

A partir de então, reconhecemos mais claramente a trama especificamente satírica pela qual o deslocamento dos filósofos de Chipre para Alexandria é também uma trajetória moderna das ideologias para se separar ainda mais de suas relações com o mundo do trabalho e da materialidade da vida. As especulações dos sábios pretendem bastar a si 
mesmas, como "a filosofia bastava ao filósofo" (ASSIS, 2007, p. 193). Assim, o que tal ciência pode compreender da realidade parte de uma abstração cada vez menos reconhecível na medida em que é impedida de historicizar a si mesma, compreender-se como parte de um todo social composto por todos os homens e em relação de dependência com isso. Assim, podemos entender que, mais que uma sátira da ciência, estamos diante de uma sátira da verdade imortal que procura seu ninho numa terra que "era grave como a íbis pousada numa só pata, pensativa como a esfinge, circunspecta como as múmias, dura como as pirâmides; não tinha tempo nem maneira de rir" (ASSIS, 2007, p. 193), já que em outras terras esse avanço sublime das ideias não podia ser levado a sério.

De fato, não só sobre ciência é o “Conto alexandrino', assim como não só nos procedimentos laboratoriais cruéis se baseia o desconforto que atinge o leitor quando é levado a saltar das cobaias animais às humanas. Lúcia Granja (2009) verifica, ao tratar da materialidade do veículo em que Machado publica esse conto, que, em 1883, eram já rotineiras as seções de ciências que davam notícia minuciosa e com grande expectativa dos experimentos com roedores, inclusive da vivisseção. Notícias sobre casos esdrúxulos de operações médicas chegam a ser comentadas por Machado em notas.

Em seu artigo, Granja traz uma descrição de experimentos com cobaia viva que parecem familiares aos leitores de "A causa secreta" e de "Conto alexandrino".

No texto, percebemos que experiências como essa citada prosseguiram durante todo um dia, tendo como cobaias ratos e bichos um pouco maiores (como o porquinho-da-índia). $\mathrm{O}$ recorte nos parece suficiente para mostrar que a sessão médica de experimentos em questão é tão "assustadora" quanto a do "Conto alexandrino". No entanto, temos aqui um relatório cuja divulgação era não só esperada, mas mesmo elogiada pelos jornais. Frente a isso, é impossível deixar de perceber que o leitor da época habituava-se a, em nome, por exemplo, da divulgação científica, ler a descrição miúda de algumas práticas médicas experimentais. Nesse caso, qual é o grau de horror que a recriação de uma experiência de vivisseção de ratos e cobaias produz no ambiente de ficção? Se naquele caso a incisão toca o coração, aqui ela é feita na coxa, mas continua pela introdução da seta pontiaguda e envenenada na ferida do animal, que de- 
pois de solto corre até morrer. Não há de ser nas "minúcias" que um caso se tornará mais terrível que o outro. (GRANJA, 2009, p. 112)

Assim, esse desconforto do leitor sobre as minúcias será atiçado em parte pela comédia de erros que faz com que os virtuosos filósofos sejam levados por sua vez aos ferros, mas não pode falar por si só, já que entramos no ponto em que o conceito de humanidade possui uma escala em que os delinquentes já não podem ser considerados, pois perderam as características humanas que seriam a virtude e a razão. A trama de erros faz com que Pítias e Stroibus encontrem, nesses termos, o impasse de sua natureza humana, uma vez que pela ciência é que se decidiram a sacrificá-la. Mas, mais do que isso, voltamos ao problema que interessa particularmente à literatura, mas que é também nesse conto o objeto da ciência, o do princípio da humanidade, das paixões, virtudes e vícios. Porém, sabemos que no realismo próprio de Machado, as várias doutrinas flutuam levianas dentre as relações produzidas pela estrutura social escravocrata. Aqui, a escala humana seria um tanto tortuosa e a sensibilidade diante da crueldade tem uma lógica própria que, por outro lado, torna o sofismo de Herófilo uma tarefa de principiante. Ainda assim, ambas as formas de pensar se encontram como velhas conhecidas e aqui vemos o travo amargo do conto.

A mistura de estilos é uma característica formal que Auerbach (2004) associa ao Romantismo como uma das grandes contribuições ao realismo. E, se tomarmos o desfecho como síntese do conto, pensaríamos que poderia se tratar de um desenlace trágico. Mas essa abstração não é possível, porque Machado produz um todo fechado. Há ainda elementos de fábula e principalmente do cômico que se integram aqui. Tratando de uma cena de Balzac, Auerbach (2004) afirma que a mistura de estilos permite que personagens de diferentes classes sociais sejam incorporados à literatura séria. E, apesar dessa forma the parecer evidente, há também questões racionais de ordem teórica que se apresentam como explicação de sua arte realista. Auerbach (2004) fala, então, da comparação entre reino animal e sociedade humana que Balzac retira dos sistemas de biólogos, místicos e filósofos e depois trata de uma concepção historicista do romance de costumes de Balzac, filiada à obra de Petrônio e que compreende, assim como as diferentes espécies, os diferentes estilos numa totalidade scottiana: 
Depois desta transfusão do biológico no histórico-humano, Balzac prossegue com uma polêmica contra a historiografia habitual, à qual lança em rosto ter negligenciado até então a história dos costumes; esta seria a tarefa à qual ele ter-se-ia avocado. Com isto, não menciona os ensaios de história dos costumes que foram feitos a partir do século XVIII (Voltaire); portanto não se chega também a uma análise que explicasse a diferença entre a sua representação dos costumes e a dos seus eventuais predecessores; somente menciona Petrônio. Ao observar as dificuldades da sua tarefa (um drama com três ou quatro mil personagens), sente-se encorajado pelo exemplo dos romances de Walter Scott; movimentamo-nos, estritamente, no mundo do historicismo romântico. Também aqui a clareza do pensamento vê-se prejudicada pelas formulações cheias de efeitos e fantasia; por exemplo, faire con currence à l'Etat-Civil é incompreensível, e a frase le hasard est le plus grand romancier du monde necessita, dentro de uma mentalidade histórica, ao menos de um comentário. Contudo, alguns motivos significativos e característicos emergem com êxito: antes de mais nada a concepção do romance de costumes como história filosófica e, em geral, a interpretação energicamente sustentada por Balzac também em outras partes, de que a sua atividade deve ser considerada como historiografia (ainda voltaremos a este ponto), outrossim, a justificação de todas as espécies e de todos os níveis estilísticos em obras deste gênero; e, finalmente, a sua intenção de superar Walter Scott, na medida em que encerra todos os seus romances num conjunto único, numa representação global da sociedade francesa do século XIX, o que volta a designar aqui como obra histórica. (AUERBACH, 2004, p. 426-427)

Para nós, a temática romântica do mundo reformado pelo homem, no conto de Machado, perde sua pretensa tragicidade diante da farsa construída, mas amplia ao mesmo tempo o ridículo ao confirmar a degradação daquela verdade contra a qual nada pode se levantar e parece legitimar os maiores absurdos. Esse prometido avanço próprio da decadência ideológica faz com que Pítias cogite em estudar o despropósito de Stroibus enquanto fixava os olhos no mar e compreendesse a situação deslocada em que estavam os dois filósofos saídos de Chipre em busca de reconhecimento, no entanto, afasta os filósofos do riso para devolvê-los a ele.

O momento final é o do sacrifício de Stroibuse Pítias à ciência, o paradoxo dos anatomistas anatomizados. A caminho da morte, cuja 
natureza ignoravam, os dois ainda furtaram figos e uma flauta, o que levou os anatomistas a considerar aquele um caso extraordinário, lindíssimo, diante do qual não podiam refrear a curiosidade científica de verificar se o nervo do latrocínio residia na palma da mão ou na ponta dos dedos. Os filósofos pediram que a vida lhes fosse poupada, porém Herófilo lhes respondeu com uma armadilha dialética, cuja estrutura refinada os deixou sem escolha. Foram ambos retalhados fibra por fibra por oito dias; berravam, choravam, suplicavam, mas Herófilo argumentava pacificamente em favor da ciência. A postura do anatomista contamina o narrador do conto, que dá detalhes do experimento com a mesma naturalidade de Herófilo: "Não falo da extração do estômago de ambos, por se tratar de problemas relativamente secundários, e em todo caso estudados e resolvidos em cinco ou seis indivíduos escalpelados antes deles" (ASSIS, 2007, p. 199).

Dessa forma, o conto justapõe de forma imediata, conseguida pelo tom de naturalidade não moralizante, ciência e barbárie. Dessa configuração satírica sobressai o que é um eixo na obra de Machado, o desmascaramento de uma galeria de homens ilustres e respeitáveis, inventados ou recriados de maneira irônica - Brás Cubas, Bento Santiago, Stroibus, Pítias, Ptolomeu e Herófilo -, homens de bem que revelam, na justaposição satírica entre sua posição social e suas ações, entre sua ciência e sua irracionalidade, entre o seu tamanho público e a sua estatura real, as contradições estruturais da vida social sob o progresso contraditório do capitalismo periférico e central. A inferiorização satírica desses homens de posição elevada se desenvolve em conjunto com a degradação que eles impõem aos homens vivos, os criminosos, que emergem do conto, sem alarde retórico, na sua real dimensão humana.

Por fim, depois de toda a carnificina ilustrada, o conto termina com uma curiosa observação do narrador, apresentada em uma forma de expressão anticientífica, mais próxima de um rumor popular: "Diziam os alexandrinos [...]" (ASSIS, 2007, p. 199). Os personagens do parágrafo final agora não são mais os homens da ciência nem os criminosos, mas os "ratos cães, rolas, pavões e outros animais ameaçados de igual destino". Os primeiros celebraram com danças e festas, num rascunho de festival totêmico, esse caso aflitivo e doloroso, mas nenhum dos outros animais aceitou o convite feito pelos ratos para participarem da 
celebração, pois um cachorro lhes disse melancolicamente: "Século virá em que a mesma coisa nos aconteça" (ASSIS, 2007, p. 199). O conteúdo dessa historieta inserida nos instantes finais do conto e em contraste com o conjunto da narrativa, remete à fábula, mas não é moralizante, sentimental ou conformista, é satírica, livre da melancolia romântica e do cientificismo naturalista, pois à melancólica predição do cão, se justapõe a libertadora resposta irônica de um rato: "Mas até lá, riamos!" (ASSIS, 2007, p. 199).

\section{NOTAS}

1. Em 1837, com apenas 19 anos, Marx escreveu, em razão do sexagésimo aniversário de seu pai, um breve romance satírico - Escorpião e Félix -, reeditado em 2018 pela Boitempo, no qual, satirizando a moral e as convenções burguesas, elaborou uma passagem que segue a mesma forma satírica de pares antinômicos, como observado pelo tradutor Tercio Redondo, presente em $O 18$ de Brumário de Luís Bonaparte, de 1852: “o heroico César deixa atrás de si o ator Otaviano; o imperador Napoleão, o rei-burguês Luís Felipe; o filósofo Kant, o cavaleiro Krug; o poeta Schiller, o conselheiro da corte Raupach.” (MARX, 2018, p. 12-13)

2. Trata-se de uma citação de Marx e Engels inserida pelo segundo em Para a história da Liga dos Comunistas: "Escrevíamos isto, Marx e eu, na "Revue von Mai bis Oktober 1850", na Neue Rheinische Zeitung. Politischökonomische Revue, fascículos V e VI, Hamburg 1850 p. 153.” (ENGELS, 1982, p. 211)

3. A citação de Marx é retirada da interessante nota do tradutor de Escorpião e Félix Tercio Redondo em MARX, 2018, p. 11-13.

“ISN'tTHAT THE GOdS' AFFAIR?” The SATIRE AND THE REAL STATURE OF THE GREAT EXILED MEN IN MARXAND Machadode Assis

\section{AbSTRACT}

This article takes on the satirical composition of two texts which are different in stylistic, spatial and chronological terms: Heroes of the exile, a parody and a political text, written in London in 1852 by Marx, Engels, Ernst Dronke and Jenny Marx, and "Alexandrian tale", a fictional narrative by Machado de Assis, 
published in 1883 in Rio de Janeiro. Far from disregarding the differences between the texts, the analysis seeks to understand the rationale behind the use of satire by both authors, which is materialized through the characters' configurations that, in exile, assume a stature that does not correspond to their actual height.

Keywords: satire, Heroes of the exile, Marx, "Alexandrian tale", Machado de Assis.

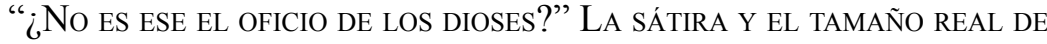 LOS GRANDES HOMBRES DEL EXILIO EN MarX y Machadode Assis}

\section{RESUMEN}

En este artículo se aborda la composición satírica de dos textos diferentes en cuanto al género, al espacio y al tiempo: Los grandes hombres del exilio, texto político y paródico, escrito en Londres, en el año 1852, por Marx, Engels, Ernst Dronke y Jenny Marx, y "Conto alexandrino", narrativa ficcional de Machado de Assis, publicada en 1883, en Río de Janeiro. Sin desconsiderar esas diferencias entre los textos, el análisis busca comprender a qué necesidad responde esa elección de los autores por la sátira, concretada a partir de la configuración de personajes que, en el exilio, asumen una estatura que no corresponde a su tamaño real.

Palabras clave: sátira, Los grandes hombres del exilio, Marx, "Conto alexandrino", Machado de Assis.

\section{REFERÊNCIAS}

ASSIS, Machado de. Conto Alexandrino. In: 50 contos escolhidos de Machado de Assis. Seleção, introdução e notas John Gledson. São Paulo: Companhia das Letras, 2007. p. 191-199.

AUERBACH, Erich. Na mansão de la mole: a representação da realidade na literatura. In: Mimesis: a representação da realidade na literatura ocidental. São Paulo: Perspectiva, 2004. p.405-442.

CHICOTE, Francisco García. Sátira em Marx y Engels. Revista Cerrados, v. 27, n. 47, p. 58-78, 2018.

. Sobre Los grandes hombres del exilio, de Karl Marx y Friedrich Engels. Exilibris, Revista del Departamento de Letras da Universidad de Buenos Aires, n. 4, p. 531-536, 2015. 
COSTA, Flávio Moreira. Batracomiomaquia (A guerra entre rãs e ratos). In: Os cem melhores contos de humor da literatura universal. São Paulo: Pocket Ouro - Martins Fontes, 2009.

ENGELS, Friedrich. Para a história da Liga dos Comunistas. In: Obras escolhidas. Tradução José Barata-Moura. Lisboa; Moscovo: Edições Progresso; Avante, 1982. (tomo III). p. 192-212.

GRANJA, Lúcia. Antes do livro, o jornal: "Conto Alexandrino". LusoBrazilian review, Board of the Regents of the University of Wisconsin Sistem, v. 46, n. 1, p.106-114, 2009.

LUKÁCS, György. A questão da sátira. Arte e sociedade: escritos estéticos 1932-1967. In: COUTINHO, Carlos Nelson; NETTO, José Paulo (Org.). Rio de Janeiro: UFRJ, 2011. p.163-191.

MARX, Karl. Contribuição à crítica da filosofia do direito de Hegel. Introdução. São Paulo: Expressão Popular, 2017.

. Escritos ficcionais: Escorpião e Felix; Oulanem. Tradução Cláudio Cardinali, Flávio Aguiar e Tercio Redondo. São Paulo: Boitempo, 2018.

Paulo: Boitempo, 2011.

. O 18 de Brumário de Luís Bonaparte. Tradução Nélio Schneider. São

MARX, Karl et al. Los grandes hombres del exilio. Buenos Aires: Las cuarenta, 2015.

SALINAS, Martín. Karl Marx y Friedrich Engels. Los grandes hombres del exilio Herramienta, Revista de debate e crítica marxista, n. 58, p. 2015. Disponível em: <https://herramienta.com.ar/articulo.php?id=2539>. Acesso em: 01 jul. 2018.

SOTELO, Laura. Acerca de Los grandes hombres del exilio de Marx, Engels y Dronke. Constelaciones, Revista de Teoria crítica, n. 7, p.266-289, 2015.

Submetido em 21 de janeiro de 2019

Aceito em 21 de janeiro de 2019

Publicado em 11 de abril de 2019 